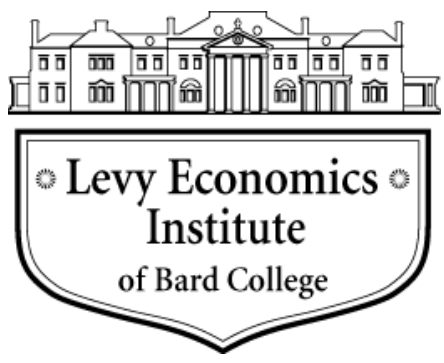

Working Paper No. 982

\title{
The Economic Problem: \\ From Barter to Commodity Money to Electronic Money
}

by

\author{
Jan Kregel \\ Levy Institute
}

January 2021

The Levy Economics Institute Working Paper Collection presents research in progress by Levy Institute scholars and conference participants. The purpose of the series is to disseminate ideas to and elicit comments from academics and professionals.

Levy Economics Institute of Bard College, founded in 1986, is a nonprofit, nonpartisan, independently funded research organization devoted to public service. Through scholarship and economic research it generates viable, effective public policy responses to important economic problems that profoundly affect the quality of life in the United States and abroad.

\author{
Levy Economics Institute \\ P.O. Box 5000 \\ Annandale-on-Hudson, NY 12504-5000 \\ http://www.levyinstitute.org
}

Copyright (C) Levy Economics Institute 2021 All rights reserved

ISSN 1547-366X 


\begin{abstract}
The success of alternative payment systems has led to discussion of various proposals to replace money with a new technology-based system, though many lack a clear idea of what exactly is the "money" they seek to replace. We begin by presenting the explanation of money's role in the economy embraced by most mainstream economists and policy analysts, based on the idea that money evolved out of the process of market exchange. An alternative explanation that looks on money as a part of the organization of production and distribution based on network clearing systems across balance sheets expressed in a common unit of account is then presented, distinguishing between a purely notional unit of account and means of settlement or discharge of debt. The final section addresses the possibility of a fundamentally different modern extension of this alternative approach that is not inspired by digital technology, distributed ledger accounting, or application operating on a mobile/cell phone system, but rather the actually existing system available from an internet telephone service provider that currently offers subsidiary domestic and international payment services whose operating procedures come close to replicating the alternative explanation of money mentioned above, with the potential to provide all the services of the existing payments system at lower costs and greater stability.
\end{abstract}

KEYWORDS: Banking Principle; Clearing Union; Imaginary Money; Money; Payment Systems; Unit of Account; Webtel.mobi

JEL CLASSIFICATIONS: B5; E42; E50; G2 
In economic policy circles, recent discussion has centered on the definition of "money," but without a clear definition of the concept. Larry Summers (2016) and Willem Buiter (2015) have recommended the straightforward abolition of money, at least in the form of currency notes and coin. On the other hand, Lord Turner (2013) proposes that the currency notes that Summers and Buiter want to abolish be dropped on the unsuspecting population from a helicopter.

Against this background, a mysterious Satoshi Nakamoto (2008) proposed a digital currency, bitcoin, should replace money, reigniting interest in Friedrich Hayek's (1976) proposal for the "denationalization" of money. In this vein, there was soon a proliferation of imitators of what came to be called "cybercurrencies." They were soon joined by a proliferation of mobile phone apps offering payment systems such as PayPal, Apple Pay, Google Wallet, Facebook libra, and Alipay that offered to replace the disappearing currency.

The success of these alternative payment systems has led most of the world's central banks to investigate the introduction of their own digital currency to replace their own issued notes. These proposals have been broached with caution because of the threat they pose to the use of private bank deposits. But to assess these various proposals for replacing money with a new technologybased system, it is important to have a clear idea of what exactly is the money they seek to replace.

We start by explaining money's role in the economy that is embraced by most mainstream economists and policy analysts. It is based on the idea that money evolved out of the process of market exchange. In this approach, money possesses or represents a physical attribute that supports its economic value. This is the kind of money - bank notes or precious metal coinsthat could be dropped from a helicopter and could be abolished.

Then an alternative explanation is presented, one that once dominated economists' discussions but has fallen out of favor. It looks at money as part of the organization of production and distribution based on network clearing systems across balance sheets that is expressed in a common unit of account. It distinguishes between a purely notional unit of account and means of 
settlement or discharge of debt. This unit of account could be changed, though not replaced, and clearly cannot be dropped from the sky but could easily exist in the cloud.

The final section addresses the possibility of a modern extension of this alternative approach. This approach differs fundamentally from those mentioned above in that it is not inspired by digital technology or distributed ledger accounting, nor is it an application operating on a mobile/cell phone system; it is rather a currently existing system available from an internet telephone service provider that offers subsidiary domestic and international payment services. Interestingly, its operating procedures come close to replicating the alternative explanation of money mentioned above, with the potential to provide all the services of the existing payments system at lower costs and greater stability.

\section{THE MAINSTREAM VIEW-MONEY AND EXCHANGE}

Modern economics developed around the implications of the division of labor highlighted by Adam Smith in the Wealth of Nations. Smith drew contrast between an economy organized around self-provisioning by multitasking hunter-gatherers subsisting by their own capabilities and an economy based on the specialization of tasks within the production process (he referred to a pin factory in which each worker specialized in one specific stage of production) or specialized in different productive activities (his famous reference to the butcher, the brewer, and the baker). In the specialized economy, the provisioning for survival of the individual depends on access to the specialized output of other producers. How was the butcher to acquire bread if he no longer produced it himself? The answer was market exchange, regulated by relative market value, which became central to the description of economic organization. For Smith, division of labor increased productivity, but could only be exploited if the market were sufficiently large, leading to successful economies being characterized by larger production units and concentration of ownership via the accumulation of capital. 
Smith was followed by the French economist J. B. Say, who notes with wonder the fact that all the specialized activities in a grand city such as Paris are somehow organized to make sure that milk arrives on his doorstep every morning and he is able to survive on provisions that are available without any formal or central direction of these activities. The independent actions of individual producers exchanging in a free market under the competitive price system are sufficient to organize this process of distribution without the need for any formal central plan or control. He expanded on Smith to note that since specialized producers would always need the output of other specialized producers, supply would always enter the market as a demand to exchange for others' output, from which he drew the unwarranted conclusion that there could never be a deficiency of demand in the market since every unit produced was either for own use or to be used in exchange.

The attention to the role of the market and prices as efficient allocators was also an organizing principle of the New Deal's brain trust, which recognized the growth of ever-larger units of production would require some oversight and regulation to ensure efficient use and allocation of resources.

Note that the basic problem to be resolved is that of exchanging specialized outputs for other specialized outputs. Initially the problems of market exchange and value were thus considered in terms of bilateral exchange ratios. If I want bananas, I can acquire them by offering some of my production of oranges. A voluntary exchange will thus determine the number of oranges that will induce the banana producer to exchange. If the exchange takes place at two oranges for a banana, then the market value of oranges is established at one-half a banana. Changes in these relative values will thus determine production in the economy. A higher offer of oranges for a banana creates an incentive for banana producers to expand their production. What appeared to be a selfregulating mechanism needed only voluntary exchange in competitive markets, no central organizing system required.

With multiple products in the economy, exchanges by individuals were organized so that the satisfaction or utility from the consumption of each would be determined by equalizing the utility derived from the quantity of each good acquired in exchange. If the satisfaction derived from the 
consumption of each good differed across products, the completion of this search for the greatest possible satisfaction from an individual's specialized output required that the satisfaction derived was inversely related to the number of units acquired (denoted as diminishing marginal utility or value).

In this version of market efficiency in allocation and relative price determination it was assumed that the exchange ratios were determined by a process of bilateral bargaining or barter. But this was clearly a very inefficient method of ensuring maximum satisfaction, since an economy with n outputs would have $n(n-1) / 2$ bilateral exchange ratios that had to be considered and require massive brain power to compare orange prices for bananas with apple prices for avocados and so forth.

The required exchanges would also be time consuming, for one could not guarantee that the supplier of the goods required would be present in the market to execute the exchange and, even if this fortuitous circumstance were to occur, there was no guarantee that the counterpart was willing to exchange the particular quantity desired to reach maximum satisfaction. This is the problem known as the "dual equivalence of wants," to which money provides the solution.

Note that up to this point there has been no reference to money. Economists noted that if the exchange ratio of each good is expressed relative only to one commodity, then the number of relative prices can be reduced to $n-1$. A massive increase in market efficiency. This commodity thus served as a benchmark for the relative exchange ratios, and this is where money entered the analysis as the handmaiden of exchange, the grease that allowed the wheels of commerce to progress.

But to play this role money had to be a commodity that was part of market exchange, but only used as an intermediary to acquire something else, not for its own benefit. Money was described by economists as a "veil" that masked the underlying real bilateral exchange ratios, and monetary analysis was thus focused on the characteristics of the commodity that could best serve as this general intermediary or benchmark while having little impact on the real exchange and production relations of the economy. 
The most important impact would be if there was a sudden change in the quantity of the commodity available relative to the fixed amounts of other commodities, the result being an increase in the relative prices of the other goods in terms of the monetary commodity that was proportional to the expansion in its quantity. Monetary theory became the study of inflation and deflation, without any impact on the level of activity, while economists argued about whether the change in prices was due to the action of money or the real production conditions of the other commodities.

There was an inherent paradox in this approach: for if the "commodity money" represented by metal coin was to serve in maximizing satisfaction, its value in terms of other commodities had to remain stable. But since it was also a commodity with a value subject to market forces this was impossible. Monetary policy thus concentrated on conditions that would prevent inflation or deflation and maintain the value of money over time as a store of purchasing power or saving.

Money is the intermediary that facilitates exchange because it is a countervalue exchanged in the market, but if it is to play this role it should have a value independent of the market. It was also supposed to have a stable value but, as noted above, if the value of goods changed with the quantity possessed (diminishing marginal utility) it was a contradiction in terms to speak of a money representing a stable value in terms of goods since their value was not stable.

This internal inconsistency was further complicated by bankers issuing notes or deposits that served as substitute means of payments, but clearly had no inherent commensurate value in exchange. Here it was the operation of the market that was at work, as the safety and transport of gold represented a substantial cost and mechanisms came in to play to substitute commodity money with bills of exchange and time contracts such as futures and options.

The bankers for their part also soon realized that payments could be made by means of netting on the banks' books by means of what came to be called the "banking principle" without any movement of "real" money. These soon came to be called "fiat" or "fiduciary" money, indicating that their value was linked to the faith in the honest behavior of the bankers who issued them. 
This good behavior was resolved as considering them as "signs" or one-to-one representation for the physical commodity money that was presumed to remain in the bankers' vaults.

The system thus nearly banished the use of commodity money metal, but the belief in the need for some intrinsic value for money led to formation of prudential policy imposing this one-to-one relation between the fiduciary issue and commodity money. It could then be argued that the public accepted the valueless paper notes because they had faith in the fiduciary holding of "real" commodity money in the banks' reserves.

Monetary history stands in judgement on the impossibility of imposing this limit, and eventually the financial system simply eliminated the reserves of metal and created central banks to control of the creation of money by banks. This system has been no more successful than the original based on commodity money since there is no way to overcome the inherent paradox in this approach to money. Yet, policy and regulations continue to be formulated so as to make the system behave as if it were based on commodity money.

Recently, a new form of commodity money—a digital coin—was launched, further highlighting the inherent paradox in commodity-based money. It has a strictly controlled change in supply and a maximum limit on creation over time but has failed as a means of payment because of the extreme variability in its price relative to commodities and the volatility of its exchange with national currencies.

\section{BUT WHAT IF BARTER WAS NEVER A PROBLEM? DID MONEY STILL EXIST? THE ALTERNATIVE EXPLANATION}

The commodity money approach just described is in fact a rather modern conception, which dates from the end of the 19th century. It sought to replace the alternative theoretical representation of money that Luigi Einaudi dates from the 9th century and Keynes suggests prevailed for some 4,000 years. 
Its modern revival is buttressed by the recognition that there exists no verifiable historical record of specialized market exchange ever having commenced on the basis of bilateral barter exchange, nor of a process of evolution from barter to commodity-money-facilitated exchange in response to the so-called difficulty caused by the double coincidence of wants that barter is supposed to encounter. Second, on the side of organization, the single benchmark for prices employed to reduce the number of bilateral exchange ratios can be more easily and efficiently carried out by means of a notional unit of account, what Einaudi ([1936]1953) has identified in the historical record as "imaginary" money.

According to Braudel's (1992) historical description of the evolution of market capitalism, the modern classical definitions of money set out above "leave out the essential point - the monetary economy itself, the real reason for the existence of money. Money only becomes established where men need it and can bear the cost." Indeed, rather than a linear evolution from barter to money, Braudel $(1992,439)$ emphasizes the simultaneous existence of monetary exchange and what is better called "exchange in-kind" rather than bilateral barter exchange: "Commodities were commonly exchanged for one another in Naples," without the intervention of a money commodity as late as the 18th century. These real exchanges required "all parties agreeing to abide by prices which the authorities fixed later (prices called alia voce). Then each consignment of merchandise was valued in money and exchanged according to the ratio of these values" (Braudel 1992, 470).

Exchange in-kind clearly existed, but it did not give rise to the inefficiencies that were supposed to have led to a commodity money to resolve the problem of the dual equivalence of wants. Braudel $(1992,447)$ also provides a description of the United States in 1791: "it is the practice here for country people to satisfy their needs by direct reciprocal exchanges. The tailor and bootmaker go and do the work of their calling at the home of the farmer who requires it and who, most frequently, provides the raw material for it and pays for the work in goods." 
Steven Stolle $(2017,112-13)$ confirms this practice in the US frontier, citing the accounts of "Nimrod Warden" who recorded that he had " "bartered with a north-country merchant 6 Hhds [abbreviation for hogshead] of claret at $£ 10$ per Hhd for 40 pieces of linen cloth at 30 s per piece.' ... The north-country merchant did not swap cloth for wine, he paid sixty pounds' worth of cloth for sixty pounds' worth of wine. If one quantity had a higher agreed-upon value than the other, a scratch in the account book rectified credit or debt to be settled another time or folded into another transaction where the discrepancy would be absorbed." ... "Just because money was ... absent did not mean that it played no part in exchanges. ... To understand why, consider this definition from an English work of arithmetic published in 1789: 'Barter, adjusts the exchange of one Commodity for another, so as neither Parties shall sustain Loss.' ... In order to barter, each party must first determine the money value of their goods. They come to the table with this worth in mind. Barter is an exchange of things measured in some currency without currency present" (Stolle 2017, 111-12).

In these historical accounts the physical exchanges are recorded in-kind and valued in an agreed upon unit of account, with any possible divergence rectified by subsequent compensation in appropriately unbalanced bilateral exchanges or by the clearing of accounts at the end of an agreed upon period. This provided for a system of real exchanges without satisfying the dual equivalence of wants and size for each exchange.

In the 18th century, in reference to the US evidence above, Braudel $(1992,447)$ notes: "These sorts of exchanges cover many objects; they write down what they give and what they receive on both sides and at the end of the year they settle with a very small quantity of coin, a large variety of exchanges... a means of wide circulation without coin ... [is created]." Commodity money is not needed to alleviate the difficulty created by the absence of the dual coincidence of quantities.

Indeed, Stolle $(2017,112)$ points out that the classical emphasis on the emergence of a single "commodity money" to serve as a reference for exchange ratios would thus seem to presume "that no one in the murky past had the brains to buy stuff in order to resell it." 
In these historical descriptions, individuals may engage in unilateral transactions or bilateral transactions in physical goods without direct monetary compensation in the form of a single commodity money. Instead, records of receipts and delivery are kept and evaluated at prices expressed in a common notional unit of account. These accounts are settled over time or on a periodic basis by means of a netting or clearing process without requiring the use of any physical money coin or commodity.

Thus, a household may receive five rabbits, which are recorded as a debit (credit on the books of the supplier) in terms of some commonly accepted unit. Next week the recipient may supply the rabbit producer with a bushel of carrots. Now he is short rabbits and long carrots and may have a net surplus or debit balance in terms of the unit of account. If at the end of the period the accounts balance then no compensation is required. If one party is a net creditor, they have the option to receive additional physical goods in excess of current needs - say a rabbit—or to allow the debt to be carried over. While it is possible to clear accounts by the transfer of coin, it is not necessary to the process of exchange. It is in this sense that Braudel and Stolle both propose the simultaneous operation of a money and nonmonetary economy.

Here the money commodity is a sufficient, but not necessary, means of exchange in real terms. It is one of several different methods for settling trade imbalances. The necessary condition is the existence of a common unit of account in which to calculate the net balances, which as Einaudi ([1936] 1953) has demonstrated with reference to historical records of Europe from the middle ages may have no physical existence; he calls them "imaginary money." He also notes the difficulty that the modern economist faces in understanding this system because coined metal pieces were widespread in this period, but they did not serve as units of account, only as means of settlement for imbalance calculated in terms of the notional units of account. 
Einaudi $(1937,265)$ emphasizes this point:

\begin{abstract}
Books and pamphlets and statutes of the ninth to the eighteenth century are unintelligible if one does not bear in mind the distinction between money of account or imaginary money and effective or coined money. Usually the money of account was called libra, livre, lira. Men kept accounts, drew instruments of debt, sold and bought goods and securities and property rights in imaginary money, which they never saw. Coins had strange names, they poured into each country from all parts of the world, were gold and silver and half silver dresses, were minted at home or by foreign princes. They made no difference to people who continue to talk and negotiate and keep accounts in libras.
\end{abstract}

Note that in this approach the unit of account replaces the commodity money as the common unit to calculate the relative value of goods in exchange. The advantages of this solution are that there is no need for money to be a physical commodity and it overcomes the supposed difficulty of barter exchange as simultaneous exchange of similar commodities or value. Nor does exchange have to be bilateral if there is a common set of books recording exchanges. Money is not a physical thing, but rather a system of account recording settlements in a common notional unit of account. While commodity money or coin may play a role in such systems as a means of settlement, it is not necessary, which leads to the idea of the simultaneous historical presence of both physical and monetary exchange.

On the abstract level this system could be represented as requiring a notional unit of money of account, that following Einaudi may be called "number." There are no number coins minted, nor are their promissory notes issued in numbers. A "number" is merely a number, an abstract notion like time or distance used for keeping accounts and expressing prices. All individuals' accounts are kept and settled in numbers. All debts, taxes, salaries, and wages are expressed in numbers. If coins are minted, they will be of some commodity or precious metal, say gold (although many different metals may be used simultaneously) of a given quality or fineness, with a specific weight, though coins of many different weights may also be present. On the face of the gold coins, only the word "libra" is present. Similarly, banks may issue notes payable in so many gold libra and pay metal of the required coins against notes in libra. 
Since numbers have no physical existence, only gold libra coins may be used to settle an imbalance or extinguish a debt incurred in an amount expressed in number. Incomes will be fixed at so many number per pay period and extinguished by rendering the appropriate number value of gold coins. The key to stability in the system is in the determination of the "appropriate amount"- the rate of exchange between the unit of account and coin. Historically this ratio is determined by the sovereign or the state setting the value in number (money of account) of the gold libra coins (means of settlement). If the rate is fixed at 10 then a salary of 100 number will be received as 10 gold coins.

In this system the physical exchanges that take place give rise to bookkeeping entries - credits for suppliers, debits for recipients - at prices expressed in number. In Joseph Schumpeter's $(2014,134)$ view, money represented a "current account relation ... the idea that everyone's economic act is recorded on a real or imaginary current account. ... Each service, whether it consists in money, money claims, or goods and services charged in money, is to be credited to each person's current account, while every receipt of money, money claims, goods, services, is to be charged to it."

In such a system money does not set a limit to economic transactions since the economy cannot run out of numbers. The limit would be set by the willingness and ability of individuals to engage in productive activity and engage in the transfer of goods and services. Here economic activity determines the "creation" of number, rather than the supply of a scarce money commodity.

While over all transactions in the economy debts must match credits expressed in number, there may be imbalances across individuals, which will require clearing or settlement of individual's imbalances with the rest of the economy. If all participants require their accounts to balance, this means creditors are no longer willing to extend debtors' negative balances. In this case it is the role of the libra coins to serve as a means of settlement at their stipulated number value. 
Here the supply of gold may serve as a constraint on trade if creditors are unwilling to allow debtors to carry their negative net balances. This problem could be solved by a royal decree changing (increasing to say 20) the number value of the libra coin. This is the equivalent of an inflation in the commodity money system; note that it occurs without changing the commodity content of the coin, but simply its number value.

However, we note that there is an alternative arrangement that would allow the elimination of the effective money of settlement. If instead of individual accounts all participants in the system had accounts with a central bookkeeper who would keep track of the debits and credits in number units of account, the overall accounts would always balance, but there would still be individual imbalances that now could be automatically compensated by the central bookkeeper. If the bookkeeper is also the sovereign issuer of libra notes or mints gold libra coins they can arrange for the appropriate debts and credits in terms of notes or coins in the accounts of debtors and creditors. But since these are book entries, the notes and coins need not actually be transferred or even exist. In fact, they could be done away with (or buried in a vault or left under the sea. Pace the Trobriand Islanders). In this way the central bookkeeper has the ultimate control over creating the means of settlement in a pure credit money system.

This raises the question of why creditors would be willing to accept these libra account credits if they did not in fact represent physical commodities. The answer is that in this social accounting money of account system, credits balances have value if they can be used to extinguish debts incurred in the production of goods and services. A. Mitchell Innes $(1914,168)$ was one of the clearest exponents of this tradition: "A credit cancels a debt; this is the primitive law of commerce. ... By sale a credit is acquired, by purchase a debt is created. Purchases, therefore, are paid for by sales. The object of commerce is the acquisition of credits. ... The value of credit does not depend on the existence of gold behind it, but on the solvency of the debtor."

Hyman Minsky (1970: note 8) adopts a similar position: "For fiat money to be generally acceptable and valuable there must be a set of payments units must make for which this money will do. ... money as a liability ... acquires value in the market because there exist units, the debtors ..., which have payments to make for which this credit money will be acceptable. The 
acceptability and value of money depend on the existence of payments denominated in that money: thus fiat money ... without debtors under constraint to meet payments commitments are quite meaningless concepts."

In a commodity money approach, money is demanded because it has inherent characteristics that make it valuable. For this reason, Schumpeter $(2014,311)$ polemically argues that demand or supply cannot be applied to money as they are to physical commodity production since in a unit of account settlement system credits need have no physical existence or inherent characteristic other than that they may be used to extinguish a debt to someone else in the system: "without the intervention of banks ... it would be a case of 'purchasing power through commerce,' a method by which the economy partially could free itself from the bridle of money."

But today we do not use this account settlement system based on a notional unit of account and absence of commodity money. How did this occur? There were two drawbacks to the unit of account money system.

The first is the possibility of inequity between debtors and creditors in loan contracts denominated in the unit of account. Since only the ratio of the unit of account to gold in the libra coin is fixed externally by the sovereign state, the ratio of other commodities to gold libra may vary. Thus, a loan contract written for 100 units of account can always be discharged with 10 libra coins (leaving aside interest) evaluating libra at 10 number. The value borrowed and repaid is the same. But, if the wage has risen in the interval from 100 to 110 , then the debtor will have to work fewer hours to repay the loan - what we would now call inflation or devaluation of money. There is thus a transfer of purchasing power in favor of the debtor. It is interesting to note that Irving Fisher developed his mathematical analysis of "Appreciation and Interest" by calculating the adjustment in interest that would be required to compensate for this distributional imbalance, leading to the use of the difference between real and money rates of interest.

The second is the possibility of what is today called "control fraud" in the keeping of the accounts. Without proper surveillance, the bookkeeper has the power to create credit entries at will without corresponding debit entries (the equivalent of the banker funding a loan by creating 
a deposit account). This not only disrupts the accounting balance of debits and credits in the economy, it separates the creation of purchasing power from the process of production and can create inequity across members of the economy or relative to the government. The historical example of this is the Bank of Amsterdam, which came to ruin financing the local government.

Associated is the temptation of the sovereign to change the ratio between the unit of account and effective money of settlement. If a sovereign has borrowed to finance a war he can always "cry up" the exchange ratio (a debasement or devaluation of the unit of account [cf. Einaudi ([1936] 1953, 264)], reducing by proclamation the effective money (libra) required to meet one's unit of account liability. As Einaudi (1937, 265-68) points out,

The idea got ingrained in the minds of the people that the libra, the monetary unit of account was something invariable, however changing was the price or quotation of the effective moneys. There was something very ludricous (sic) in this conception because princes often made use of the device of increasing the libra price of coins - which was the old name of devaluation - when they desired to repay smaller sums than those received. ... True, princes misused the tool, and men were made so angry by these misuses that they threw it overboard at the end of the eighteenth century. When the people proclaimed that there was only one monetary unit, a coin of so much gold - weight and fineness - they were persuaded to think that they had made a great step in the direction of simplicity and good faith.

This was an attempt to find a money that had stable value by specifying the commodity content of the unit-in practice to specify the unit of account as the libra. In the United States, the dollar serves both purposes, as does the euro in the European Union. China still retains a remnant of the dual approach in the renminbi (RMB) and the yuan as the effective means of settlement and the unit of account. But it was impossible to hold constant the relative prices of commodities and gold, just as it was impossible to keep this ratio constant in an account settlement system. 
With reference to the solution of specifying the unit of account in terms of a gold coin, Einaudi ([1936] 1953) notes: "The gold units did not prove to be a sufficient bulwark against the manipulations of money. Against these manipulations no system whatever is invulnerable. Gold money and managed currency alike are subject to misuse."

\section{THE WEBTEL.MOBI SYSTEM AS THE BASIS FOR A UNIT OF ACCOUNT CLEARING SETTLEMENT SYSTEM}

As mentioned above, cybercurrencies such as bitcoin attempt to substitute the current reservebacked notes or coins with a digital currency backed by a binary identification system verified by calculation and distributed ledger comparison. They are meant to replace paper notes, which already bear a numerically unique serial number, with a binary identification stored on a series of computers that jointly verify the distributed ledger entries of asset transfers. But aside from being employed by the bitcoin universe (miners who carry out the transaction verification are allocated new bitcoin) it is currently impossible to acquire new bitcoin without an exchange with the formal money system so that they are neither a full-fledged unit of account nor an effective means of settlement due to large fluctuations in their dollar value. The verification system is presumed to be completely private and secure because of the distributed verification of transactions. However, the biggest difference between the bitcoin system and a settlement system is that it does not provide a balance sheet of debits and credits or provide a clearing system for net balances. Its distributed ledger system is simply a recording of credit transfers to ensure veracity and security, yet in practice it has been neither secure nor fully private. In fact, these cybercurrencies have been more successful in raising capital through IPOs of coins (called initial coin offerings or ICOs) than in providing money attributes or payment services.

To be a real competitor to the current bank-based commodity money system, the first requirement is thus to replicate the account settlement system, that is, to take on the role of bookkeeper in the banking principle arrangement cited above. 
At present there is only one system that provides this possibility. Although it is based on mobile telephony, it has a radically different structure from existing mobile transfer systems. ${ }^{1}$

In this sense Webtel.mobi (WM) is the only currently operating system that meets this condition because it plays the role of the bookkeeper of an alternative settlement system for its TEL.mobi Group (TMG) members' stored-credit values accounts through the WM system and its InterTEL.mobi account number (ITAN) account identification system. It acts as bookkeeper in the sense of crediting and debiting member accounts as they are created by transfer and used for telephony services.

A TMG member account is created via an electronic transfer into the member's account from a member's regulated bank account, card, or other traditional payment means to a currency subaccount within the WM multicurrency regulated bank account. Alternatively, an electronic transfer is made by an independent marketing agent (agent) or virtual specialized mobile provider affiliate (VSMP) to one of WM's currency subaccounts within its multicurrency regulated bank account, after which the agent or VSMP will use that stored value on their own TMG member accounts to create and issue digital top-up vouchers (TUV) to TMG members in return for physical currency paid to the agent of the VSMP. The use of agents and VSMPs in this role is to provide access to TMG's services to members without formal bank relations. Thus, the agents and VSMPs are subject to know-your-client (KYC) and anti-money laundering (AML) provisions. The possible currency subaccounts (currently 43) are determined by the geographical distribution of the systems' members.

While the transfer in both cases (direct or via affiliate) is initiated from a regulated national financial institution denominated in national currency and becomes a credit in the TMG member's account, it is recorded by the WM system in the TMG member's account purely as a

\footnotetext{
${ }^{1}$ Webtel.mobi (WM) is a global telephony company that operates as a specialized mobile provider (SMP) providing telephony services to members globally via affiliates known as virtual specialized mobile providers (VSMPs) operating a replica of its own platform and system. The ensemble of WM and its VSMPs is known as the TEL.mobi Group (TMG). Since the platforms and systems of WM and its VSMPs are fully interconnected and controlled by WM they may be represented alternatively as the WM system or the TMG system, both of which refer to the same system.
} 
ledger-entry record of the amount of stored value that the member owns within the total of all members' stored value in WM's regulated bank accounts. When opening a TMG member account, the member will have chosen a currency denomination as the primary currency wallet for the stored-value account and may also choose to hold additional accounts in other currencies (currency wallets). Thus, once the transfer is entered into the TMG system it is also recorded in the member's chosen primary currency wallet and for the appropriate amount in that currency.

The recording of the opening and changing of TMG member account balances from these initial account opening transfers - as well as additional amounts that may result from inter closed-loop member transfers (ICLMs) of stored value between members to and from their TMG accounts or additional inward transfers of stored value - may be considered as being an internal WM accounting and ledger-maintenance process, while the initial transfer remains unchanged in WM's multicurrency bank accounts and only the ledger entries of the amount held per TMG member are notionally adjusted as an internal bookkeeping procedure.

Moreover, on the TMG platforms there are two currency conversion facilities - the "currency swap" facility, an on-demand currency conversion facility functioning on the global foreign exchange (FX) markets, and the "currency swap" facility, which is a pure peer-to-peer (PP2P) member-to-member facility where members can swap their own stored value between accounts at conversion rates set between the two swapping members. Again, although the ledger entries in the respective TMG member accounts alter in these transactions, the stored value/stored credit remains static in the WM bank accounts.

Thus, just as Einaudi's imaginary units of account were convertible into a wide range of specific metallic coins that were used as means of settlement and discharge of debt, the WM stored value/stored credit is convertible into a range of national currencies that are available as means of settlement.

Thus, in difference from both cybercurrency and mobile payments system, there is a full balance sheet without the use of a dedicated mobile phone app to execute transactions. All inward transfers, currency conversions, currency swaps, or ICLMs are registered in a member's account 
as a ledger-entry/accounting change of their stored credit in the TMG system, but the currency on account resides in the same WM (multicurrency) bank accounts and it is only electronically segmented between owners as a ledger-entry alteration, which will be debited or credited in the TMG member's account according to the usage of services or transfers.

While this system is designed only to provide payment for the provision of WM telephony services, it provides subsidiary services because of its similarity to mechanisms introduced in the 1930s in Germany to fight depression and then by US banks in the 1970s to create a "cashless" society. The German Reich Railway issued transport certificates to purchase services from suppliers redeemable at railway booking for the transport of goods and persons provided by the railway. Such a scheme differs from borrowing from a bank, where there is the risk of failing to generate sufficient sales to repay the debt. In this system the services are presold and the railway, short of bankruptcy, is certain to be able to provide them.

The key to the system is a generalized need in a large proportion of the economy for transportation services, which to the proponents seemed obvious (Zander 1933). The proposal also notes that the certificates' distribution could be facilitated if they could be accepted as payment of government taxes, providing them the additional support in a system that was then in Germany called steuerfundation. ${ }^{2}$ A number of similar systems were proposed in this period, among the best known in the US was Upton Sinclair's EPIC system, which supported his candidacy for governor of the State of California. ${ }^{3}$

A similar system was employed in the United States in an attempt to eliminate cash transactions: “offline stored-value payment cards," with magnetic strips that recorded and stored prepaid credits in currency that were reduced upon use to purchase services. These payment cards, originally designed for the acquisition of specific services such as parking or transport fees, served not only to eliminate the use of cash payments, but also prevented the need for specialized

\footnotetext{
${ }^{2}$ Note that the system was tried but failed in the United States, since it was launched in order to build a railway that was never completed.

${ }^{3}$ Ending Poverty in California (EPIC) recommended production for use financed by the presale of worker production from idled plant and equipment, see Mitchell (1992). The final program is available at: https://www.ssa.gov/history/epic.html. A similar theoretical scheme of state money supported by taxation is found in Ezra Pound, e.g., "What is Money For?," influenced by the work of Major Douglass and Silvio Gesell.
} 
point-of-sale units linked by trunk telephone lines to provide credit verification and reduced the labor involved in collecting low-value payments using automatic validation units at the point of sale. This archaic system lives on in New York City's Metrocard system for subway fare payment, while most other countries have introduced embedded electronic chips or remote transfer agents (RTA) found in most mobile payment technology.

An offshoot of this system was employed by Merrill Lynch in the early 1990s when it launched its cash management accounts (CMAs) that combined a traditional brokerage margin account with check writing and credit card privileges tied to a money market mutual fund (in which Merrill was an industry leader). In essence Merrill became the client of a bank and used the accumulated credits in a client's margin account to make nonequity transactions on the client's behalf via the established system of payments of regulated institutions. The accumulated credits stored in a financial institution that was forbidden the supply of payments services had become a virtual stored value that could be accessed and spent for any good or service.

The salient characteristic of the account settlement system of monetary organization outlined above is that it operates without any physical representation of money in the financing of economic production and exchange. It provides a central system of accounts in which payments take place via a clearing or netting process, which is more efficient as more economic transactors participate.

The TMG system builds on a synchrony between the technology of internet-based communications systems and the prepayment of telephony services to generate the basic aspect of a unit-of-account-based settlement system that can provide for subsidiary payment services such as financial transfers between members and the acquisition of (noncommunications) real goods and financial services. The TMG system thus appears to have these main features to provide the basis for a modern-day account settlement system capable of substituting for the regulated bank transfer system. It is in this sense that WM can be considered as the bookkeeper for the TMG system, executing these member account adjustments via what are called "mobile operator stored-credit swaps" (SCS) that adjust the system members' debits and credits. 
But there is no reason for these to be limited to credits to a member's stored-value account or debits for service payment transactions. A TMG member with a positive net credit balance may use an SCS to transfer stored credit to another TMG member via ICLM. ${ }^{4}$ This is simply a repeat of the process whereby a ledger-entry alteration is carried out by the WM system between the two TMG members' TMG accounts, but the actual currency remains static in the WM bank accounts.

While the WM system does not use a physical storage medium to hold these stored-credit balances (such as magnetic strip or chip-embedded payment cards), it reflects the traditional banking principle model in which the TMG member has credits on their notional electronic account that are debited or credited as mobile communications or payments subsidiary services are used.

These ICLMs or mobile operator SCSs between TMG members operate just as in the 19th century banking principle and are equivalent to "in-bank transactions" in a regulated bank, thus they do not produce any changes on the WM bank regulated holding accounts in the same way that a check payment between two members of a traditional bank has no impact on the bank's balance sheet reporting requirements. Thus, just as the Merrill Lynch CMA, WM can bypass a series of prudential regulations applied to traditional credit institutions.

Obviously, this holds only for transactions within the TMG system. Payments outside the system, just as traditional banks' bank-to-bank transactions, will require changes in balance sheets and the use of an external means of payment. For US banks this takes place on Fed wire, and for the WM system the same is true if stored credit is refunded to a TMG member via the formal banking system.

\footnotetext{
${ }^{4}$ This is facilitated by each TMG member being allocated a unique TMG account number linked to their unique mobile phone numbers when opening their TMG account. This account number known as an Inter-TEL.mobi account number (ITAN). The account number system is managed by the TEL.mobi Group Inter-Tel.mobi account number system (TITAN). It ensures that ICLMs and other transactions between TMG members are carried out virtually instantaneously (in 1/100th of a second) with 100 percent accuracy, wherever in the world the respective TMG members may be, on a 24-hour basis, 7 days a week, 365 days of the year.
} 
As noted, the attractiveness of WM and the extent of its subsidiary services depends on the extent of the WM system's coverage - the activities of which it carries out via is VSMP affiliates within the TMG. In this regard the VSMPs facilitate access for individuals without a formal, regulated financial system presence (those who are usually classified as the "unbanked" but include those who prefer to use mobile payments systems). This is done via an arm's length transaction in which a digital TUV may be purchased from a KYC VSMP or agent with stored credit on the TMG system that was previously transferred into one of WM's bank regulated accounts by the VSMP or agent using the regulated bank system.

Once a VSMP or agent has stored credit on the WM system, they are able to use it to create TUVs for new or existing member accounts. The TUVs are encrypted with the specific currency and for the specific amount, as may be paid to the agent or VSMP by an unbanked TMG member with nonregulated credits (cash). Once the unbanked TMG member loads the TUV onto their TMG account, the currency and amount for which the TUV is valid is instantly recorded in their TMG account, and the person is then in the same position, and with the same capacities for use of the digital TMG system, as those who loaded their stored credit by regulated bank transfer.

In this way the unbanked have access to the services of a regulated bank as well as the telephony service access that they may not be granted or able to afford with a regulated bank. It is in this respect that the system's operation without a transfer app on the member's device enlarges the potential user population because it can be used from any existing mobile/cell phone-including pre-smart phones. Since the majority of phones in use among the unbanked and in developing countries do not have the capabilities to operate the mobile transfer applications currently offered, this insures a wider geographical coverage and penetration than existing mobile payments systems, and provides a safer and more secure alternative to public and private immigrant remittance systems such as licensed "money transmitters" or private "hawala," "hundi," or "fei ch'ien" systems. 
Employing concepts and regulatory provisions originally developed to support the cashless stored-value payments cards, these systems do not create credit, as is the case with bank loans or bank credit cards, which are subject to prudential regulation on their activities by financial regulators.

In much the same way as the repayment and credit risk on the railway certificates was reduced because the only commitment was to provide transportation, of which the railway had no risk of failure to provide, these cards' stored credits are transferred from existing payment accounts to be used for the purchase of defined services, such as telephone calls or parking services, and thus payment was always assured. In this way, unused credits for telephony services do not require prudential regulations on credit and repayment risks. As noted above, this is the equivalent to reserves in the regulated deposit banking system but is more stable because the services can be produced by the supply and do not depend on ex post sales. The creation of stored-credit accounts based on transfers from regulated banks provides the equivalent of a 100 percent reserved regulated deposit banking system. The private regulated deposit banking system cannot provide this assurance, except through the guarantee of the Federal Deposit Insurance Corporation (FDIC).

As noted above since member accounts for telephony services are offered throughout the world in the members' respective currencies, the WM multicurrency bank account will have multiple currency balances representing the total of stored credit in the underlying member accounts. This provides for the execution of ICLM transfers (SCS) between TMG members with different national currency accounts and the possibility for TMG members to access or convert other currency credits and to hold them in their called currency wallets - which are in fact merely ledger entries representing the amount of stored credit owned by the TMG member within the various WM multicurrency bank accounts.

This raises another interesting difference with respect to the historical unit of account/ clearing/account settlement systems described above. In these systems the ratio of unit of account to effective means of settlement (gold libra per number is used in the examples above) is set outside the system of individual production and exchange by a sovereign or government 
entity. The system works because everyone in the economy has debits and credits denominated in the same unit of account.

Outside of the nation state these values have no jurisdiction; they will be different according to the choices of each independent economy as to its unit of account. Imbalances across nations cannot be made or compared in unit of account and an international cross-border means of settlement will be required. It may be a commodity, as under the gold standard; it may be done through an international market in which claims on a country's means of settlement are traded at what is called the "foreign exchange rate." Or voluntary borrowing and lending in an international financial market may compensate for imbalances. The Bretton Woods System was a combination of an institution that fixed exchange rates across national means of settlement via a fixed rate relative to gold or the US dollar unit of account. All these solutions have proven to be inherently unstable and have produced periodic crises, either in the form of volatile capital flow reversals or exchange rate instability.

Keynes's clearing union proposal sought to solve the problem through a meta settlement system based on a supranational unit of account (Keynes's proposed "bancor") accepted by all participants at a fixed rate in their national unit of account and which would be the basis for automatic settlement across countries by means of adjustment in their debit and credit balances on an international balance sheet kept by a supranational authority. While this provided a technical solution, it required each member state to relinquish sovereignty over its national unit of account/means of settlement relation, and the possibility of substantial accumulations of debit and credit balances as the system only financed the imbalances but did little to eliminate them. Such proposals to eliminate imbalances also implied a loss of national autonomy in domestic fiscal and monetary policy that countries were unwilling to accept.

It is interesting to note that current proposals to substitute national currencies with electronic or digital national currencies will not solve these problems, as they would require a metasystem with a single digital equivalent of Keynes's bancor and face the same problems of countries' unwillingness to cede national sovereignty over their monetary systems and policy autonomy to limit imbalances. 
The TMG system resembles Keynes's proposal in that it provides adjustment of crosscurrency holdings of TMG members' stored credit by means of a simple bookkeeping adjustment in TMG members' ledger-entry balance records consequent to currency conversions, currency swaps, or ICLMs. Because members may hold wallet accounts in several different currencies and the TMG currency conversion, currency swap, or ICLM can only occur using stored credit already in the WM multicurrency bank accounts, this adjustment simply takes the form of a debit-credit adjustment of the stored-credit amounts from the member's national currency wallet to their wallet in another currency (if a currency conversion or currency swap) or a stored-credit transfer to another TMG member in a currency other than the receiving TMG member's national currency (if an ICLM).

With a currency swap, instead of the rates being fixed by government or through the regulated bank foreign exchange market, members swap currencies internally on the TMG system at rates set by themselves independently of the formal foreign exchange market (although the TMG system does provide alternative access via formal global FX markets). Thus, the system has opened the possibility of a fixed conversion rate or leaving the conversion rate determination to a crossing system in which the rate is set by the volume of individual transactions between TMG members at their own rates and according to open competition principles.

In the academic discussions around fixed versus floating exchange rate systems, Keynes, among others (such as Milton Friedman), suggested that contingent contracts could provide coverage against the uncertainty caused by volatility of floating rates. On the one hand, the TMG system solves this problem with the condition that swap rates are produced and presented but need not be accepted if not considered representative of the market.

On the other hand, hedging instruments such as forex forwards and futures are simply mechanisms for hedging short or long positions with the opposite position. Thus, a TMG member expecting to discharge a debt in a second currency could hedge that risk by means of a currency swap of stored credit to lock in the cost of acquiring the second currency, which can be used to meet the payment when the invoice arrives. 
Alternatively, it would be possible for one TMG member to borrow currency from another member with a positive net stored-credit balance via an SCS in the required currency and lend it via an SCS until the payment is made. In the normal forward market this transaction will depend on the rates charged on borrowing and lending in the two currencies, but there is no reason why these hedging mechanisms cannot take place within the TMG system. It would even be possible for members to offer to provide these services operating independently in the market. Since one of the advantages of the TMG system is the low cost and rapidity of accounting adjustments in its TMG member stored-credit account ledger system, these are all more rapid than money market "spot" transactions, which even with real-time gross settlement may clear during the day. To produce time transactions, as seen in the above example, would require holding long or short positions over time. These could clearly be developed by members within the system or by specifying repayment dates for ICLM (SCS) lending transactions.

This brings up a second difference with the account settlement system described above: in that system there was no limit on the expansion of credit because it used a notional unit of account. As noted there, unlike a commodity money or fractional reserve system, there is no limit on the number of "numbers" that can be created, so the only limit is the level of real economic activity. Thus, the creation of credit is driven by the real transactions in the system without limit from the physical means of settlement.

But, as the WM system is currently configured, these units are created by provision of credit transfer from TMG members' regulated bank accounts or transfers by VSMPs and agents to facilitate their posttransfer creation of TUVs for unbanked TMG members. These credit and currency transfers set the limit on the size of the TMG system. This is what provides the equivalent of 100 percent reserve backing in a fractional reserve deposit system. As noted, this means that WM does not create credit internally.

However, this limitation on credit creation is due only to internally imposed operating rules that allow WM to retain operations within the telephony sector rather than exploiting the possibility of the direct provision of financial services. As discussed above, when the unit of account is defined in terms of a physical means of settlement, as eventually occurred in many countries, the 
supply of the coin or commodity became the direct (or, in the case of imposing a reserve requirement, indirect) limit on credit creation.

It has become common for mobile operators to allow clients to purchase ancillary services via their accounts, for example, mobile phones and other accessories, as well as to provide postpaid delayed payment facilities for these purchases in exchange for contract commitments. These direct carrier billing services have also been extended to purchases of generalized goods and services through direct-to-mobile-bill payment facilities. There is no change in the system's operation if these charges are limited by prepayment. However, since WM operates as bookkeeper of the notional member accounts system there is nothing to prevent crediting members' stored-value accounts or issuing TUVs above the prepaid balances.

As mentioned above, the bookkeeper has control over the credit entries and the use of stored credit to meet billing from other users or producers. In addition, as in other historical clearing system experiences, the management of the TMG account balances and the issue of TUVs provides not only the possibility of creating credit, but of providing delayed settlement or extending periodic clearing limits to create implicit credit. With the introduction of this facility, the TMG system could provide all the functions of any current national or international financial system.

But more importantly, by allowing all national governments to retain their national units of account and sovereignty over domestic monetary and fiscal policy, it would provide for an international financial system that features all the advantages of Keynes's clearing union proposal without the political impediments (Kregel 2021). 


\section{SUMMARY}

Finally, it is clear that the proposals mentioned in the introduction cannot do anything but substitute for money in the existing regulated system. Using sophisticated distributed ledger digital technology is indeed a step back from the operation of the "banking principle" in its modern form, while the creation of digital money by central banks would have the same impact as the TMG system on the private regulated banking system's profitability and will thus face strong resistance. Such resistance already was sufficient in the 1940s to prevent implementation of the banking principle at the international level in the clearing union proposal. Finally, as is well-known, for the mobile phone payments systems such as Apple Pay or Facebook's libra to be successful would require widespread diffusion of expensive phone sets and internet connections, thereby limiting coverage to those with such access.

Thus, to recap the advantages of the TMG system, it is based on an account settlement protocol similar to the banking principle in which transactions are conducted without the use of any physical representation of money and thus without any actual movement or transfer of funds aside from debit and credit entries on the client accounts managed by the WM bookkeeper through the WM system. This mechanism was first developed by banks to eliminate the cost and insecurity of the use of a physical means of settlement—-first for physical commodity money and then for fiduciary money.

Just as over time bank notes replaced metal coin and bank deposits replaced bank notes, the Webtel.mobi System offered by the TEL.mobi Group provides an electronic account adjustment of TMG member accounts geographically separate from a member's location as a function of its global telephony services that is a full substitute for the existing private bank payments system. Its currency conversion and currency swap facilities provide TMG members with the capacity to convert their stored credit from any national currency to any other, reducing the transaction time by an order of magnitude, as well as substantially reducing fees. 
Its ICLMs between TMG members enable the swap of stored credit between members that can be used as a means of payment for any goods, services, or other medium-of-exchange-based transactions. Its ITANs for members via its TITAN system creates a unitary and global account system with virtually instantaneous global transfers between TMG members. As the stored credit in the WM multicurrency bank accounts legally remains the property of TMG members until it is used for telephony services, on a member's request WM is legally obliged to refund any unused stored credit to the member's regulated bank account or to unbanked members via an affiliate or stored-credit refund machine (WM's inter-closed loop members cash kiosks). Electronic transfer of stored credit in members' accounts and the elimination of a human presence at the transaction site also provides the possibility of substantial cost savings. The WM system is therefore capable of handling any internal or crossborder transaction currently provided by a regulated private financial institution. It provides an operational and cost advantage over both cybercurrencies systems (such as bitcoin) and mobile payment systems (such as Apple Pay, Google Wallet, and PayPal). Full exploitation of this cost and convenience advantage, as is the case in any network system, depends on the degree of concentration and penetration.

In its present configuration, the TMG system faces an internal contradiction. While it depends on transfers from the regulated banking system, its operation provides structural efficiency advantages that will threaten the banking system's survival, because credit creation depends on dominance in issuing means of payment. If bank profits are generated by net interest margins that result from the deposit creation to fund asset acquisition, the damage to bank deposits' dominance as the sole means of system payments threatens private regulated banks' profitability and survival. This is true regardless of whether the private system provides an electronic means of payment. It would be accelerated if national central banks move aggressively to provide electronic payments in response to the proliferation of cyber/electronic currencies and mobile payment systems. The banks' response to the secular decline of their net margin lending business has been to move into other activities that engender higher risks and instability.

As a result, the TMG system's success may compel it to consider implementing an adjustment to its operating protocols and a sector switch in order to allow for the extension of credit creation within TMG member accounts and by credit-based TUVs. If the system's implementation is 
successful in the sense of supplanting private banks' credit-based payments system, it would then require the development of a full-fledged settlement system that allowed for credit creation. This would clearly be a net benefit in terms of financial system stability, for it would eliminate the possibility of bank runs and bank crises that have plagued the fractional reserve financial system up to this day. 


\section{REFERENCES}

Braudel, F. 1992. Civilization and Capitalism 15th-18th Century, Volume I: The Structure of Everyday Life the Limits of the Possible. Berkeley: University of California Press.

Buiter, W., and E. Rahbari. 2015. "High Time to Get Low: Getting Rid of the Lower Bound on Nominal Interest Rates." CitiBank Global Economics View, April 9. Available at: http://willembuiter.com/ELB.pdf

Einaudi, L. (1936) 1953. "The theory of imaginary money from Charlemagne to the French Revolution.” In F. Lane and J. Riemersma (eds.), Enterprise and Secular Change. London: Allen \& Unwin.

- 1937. "The Medieval Practice of Managed Currency." In A. D. Gayer (ed.), The Lessons of Monetary Experience. New York: Rinehart.

Hayek, F. A. 1976. The Denationalisation of Money. London: Hobart Papers.

Keynes, J. M. 1930. “A Treatise on Money, Volume I, The Pure Theory of Money.” In E. Johnson and D. Moggridge (eds.), The Collected Writings of John Maynard Keynes, Vol. 5. London: Macmillan.

—. 1980. "Shaping the Post-war World: The Clearing Union.” In D. E. Moggridge (ed.), The Collected Writings of John Maynard Keynes, Vol. 25. London: Macmillan.

Kregel, J. 2021. “Another Bretton Woods Reform Moment.” Levy Institute Public Policy Brief No. 154. Annandale-on-Hudson, NY: Levy Economics Institute of Bard College.

- 2015. "Emerging Markets and the International Financial Architecture: A Blueprint for Reform.” Levy Institute Working Paper No. 833. Annandale-on-Hudson, NY: Levy Economics Institute of Bard College.

Kregel, J., and P. Savona. 2020. "The Impact of Technological Innovations on Money and Financial Markets.” Levy Institute Public Policy Brief No. 150. Annandale-on-Hudson, NY: Levy Economics Institute of Bard College. June.

Minsky, H. P. 1970. “The Reconsideration of Keynesian Economics.” Hyman P. Minsky Archive, Paper 475. Available at: http://digitalcommons.bard.edu/hm_archive $/ 475$

Mitchell Innes, A. 1914. "The Credit Theory of Money." The Banking Law Journal 31(Jan.Dec.); reprinted in L. Randall Wray (ed.), Credit and State Theories of Money: The Contributions of A. Mitchell Innes. Cheltenham, UK: Edward Elgar.

Mitchell, G. 1992. The Campaign of the Century: Upton Sinclair's E.P.I.C. Race for Governor of California and the Birth of Media Politics. New York: Random House. 
Nakamoto, S. 2008. "Bitcoin: A Peer-to-Peer Electronic Cash System.” Technical paper, November 1. Available at: http://www.bitcoin.org/bitcoin.pdf

Pound, E. n.d. "What is Money For?” Available at: https://archive.org/details/WhatIsMoneyFor

Schumpeter, J. A. S. 2014. A Treatise on Money. Aalten, Netherlands: Wordbridge Publishing.

Stolle, S. 2017. Ramp Hollow: The Ordeal of Appalachia. New York: Hill and Wang.

Summers, L. 2016. "It's Time to Go after Big Money." Blog post, February 16. Available at: http://larrysummers.com/2016/02/16/its-time-to-go-after-big-money

Triffin, R. 1960. Gold and the Dollar Crisis: The Future of Convertibility. New Haven: Yale University Press.

Turner, A. 2013. "Helicopter money as a policy option.” Institute for New Economic Thinking blog, May 29. Available at: https://ineteconomics.org/ideas-papers/blog/helicoptermoney-as-a-policy-option

Zander, W. 1933. "Railway Money and Unemployment." Annals of Public and Cooperative Economics 9(3): 163-76. 